\title{
The alpine Desmids from the Japanese Alps, 2.
}

\author{
By Minoru Hirano
}

本野 実：日本アルプスの鼓藻類 2 .

\section{Received October 22, 1952}

77. C. geometricum W. \& G.S. West var. suecicum Borge in Messikommer p. 46. pl. 4. f. 51, 52. 1935. Length $8.6 \mu$, Breadth $7.7 \mu$, Isthmus $3.4 \mu$. Hab. 16. New to Asia.

78. C. decedens (Reinsch) Racib. in West p. 43. pl.69. f. 6-8. 1908. Length 43$60 \mu$, Breadth 21-37 $\mu$, Isthmus $17-19 \mu$. Hab. 2-8,10,11,13,17,20. Distribution in Japan: Confined to the alpine region and often met with.

79. C. exiguum Arch. in West p. 63. pl.70. f. 17-19. 1908. Hab. 2,3. Distribution in Japan: General.

80. C. minimum W. \& G.S. West in p.66. pl.71. f. 1, 2. 1908. Length $10.3 \mu$, Breadth $10.5 \mu$, Isthmus $4.9 \mu$. Hab. 17. Second record in Japan. Already known from Mt, Kirishima.

81. C. pseudoexiguum Racib. in West p. 139. pl.57. f.7. 1905. Hab. 9. Distribution in Japan: General.

82. C. undulatum Corda var. crenulatum (Näg.) Wittr. in West p. 150. pl. 59. f. 11, 12. 1905. Length $25.8 \mu$, Breadth $17.2 \mu$, Isthmus $8 \mu$. Hab. 9 .

83. C. subprotumidum Nordst. var. Gregorii (Roy \& Biss.) W. \& G. S. West in West p. 232. pl.86. f. 23-25. 1908. Length $25 \mu$, Breadth $21 \mu$, Isthmus $7 \mu$ Hab. 23. New to Japan.

84. C. petsamoense Cedercreutz in p. 244. f. 12,13. 1932. Length $30.8 \mu$, Breadth $18.3 \mu$. Isthmus $8.6 \mu$. Hab. 21. New to Japan.

84a. forma simplicius Kossinskaja in p. 419. pl. 2. f. 2. 1936. Length $35 \mu$, Breadth $25.8 \mu$, Isthmus $9.8 \mu$. Hab. 21. New to Japan,

85. C. obliquum Nordst. forma tatrica Gutw. in Messikommer p. 33, 48. pl.4. f. 39. 19 5. Hab. 3-6, 8, 11-14, 17, 23. Alpine Desmid, only distributed in the alpine moor of Japan. I have often found two forms at the same time, each after the other in sphagnum bogs of the Japanese Alps, one measures in length 14-15.4 $\mu$, and in breadth $12 \mu$ and other is in length $26-27 \mu$, and in breadth 19-20 $\mu$.

86. C. contractum Kirchn. var. minutum (Delp.) W'. \& G.S. West in p.173. 1905. Hab. 9. Distribution in Japan: General.

87. C. Hammeri Reinsch var. protuberans W. \& G.S. West in p. 183. pl.62. f. 24, 25. 1905. Length 26-30 $\mu$, Breadth 19.4-23.7 $\mu$, Isthmus 7.7-8.6 $\mu$. Hab. 8, 9. Distribution in Japan: General.

88. C. venustum (Bréb.) Arch. forma minor Wille in West p. 10. pl. 66. f. 4. 1908. 
Length 24-28 $\mu$, Breadth 15.4-19.6 $\mu$, Isthmus 5.6-6 $\mu$. Hab. 6-8, 10-14, 17. Distribution in Japan: General in alpine moors.

89. Xanthidium armatum (Bréb.) Rabenh. in West p. 51. pl.104. f.1-5. 1911. Hab. 3, 8, 10-14. Distribution in Japan: Often met with in sphagnum-bogs in the alpine and subalpine regions.

90. X. concinnum Arch. in West p.86. pl.112. f. 10. 1911. Length 8.4-12 $\mu$, Breadth 10.8-11.2 $\mu$, Isthmus 5.6 $\mu$. Hab. 7, 14. Distribution in Japan: Rare (P1. 2 . f. 12.)

90a. var. Boldtiana West in p. 87. pl.112. f. 11, 12. 1911. Hab. 3,8,11,12. Distribution in Japan: Same as in the typical species.

91. X. antilopaeum (Bréb.) Kütz. var. laeve Schmidle in West p.68. pl.109. f. 3. 1911. Length without spine $64.4 \mu$, Breadth without spine $56 \mu$, Isthmus $19.6 \mu$. Hab. 10. Second record in Japan.

92. X. cristatum Bréb. var. uncinatum Bréb. in West p.73. pl.111. f.2-4. 1911. Hab. 9. Distribution in Japan: Frequently met with in swamps of low land. (P1. 2. f. 5.)

93. Arthrodesmus controversus W. \& G. S. West in p.103. pl. 115. f. 12-14. 1911. Hab. 13. Second record in Japan.

94. A. Incus (Bréb.) Hass. forma minor W. \& G.S. West in p.92. pl.113. f. 1619. 191 , Hab. 3, 4, 6-8, 10-12, 14, 15, 23. Distribution in Japan: General in sphagnumbogs in high altitude. (P1. 2. f. 11.)

94a. var. indentatus W. \& G. S. West in Taylor p. 273. pl.56. f. 9. 1934. Length without spine 13-16.8 $\mu$, Breadth without spine 10.8-14 $\mu$, Isthmus 5.8-7 $\mu$. Hab. 8,1113, 23. Distribution in Japan: General.

94b. var. Ralfsii W. \& G.S. West forma latiuscula W. \& G.S. West in p.96. pl. 114. f. 5. 1911. Length without spine 16.3-17 $\mu$, Breadth without spine 17-19.4 $\mu$, Isthmus $5.5-6 \mu$. Hab. 8. Distribution in Japan: Not general. (P1. 2. f. 29.)

95. A. crassus W. \& G. S. West in p. 102. pl. 115. f. 8-11. 1911. Length without spine $21.5 \mu$, Breadth without spine $17.2 \mu$, Isthmus $13 \mu$. Hab. Mt. Kaminotake. New to Asia. (P1. 2. f. 13.)

96. A. phimus Turn. var. occidentalis W. \& G.S. West in p.104. pl.115. f.17. 1911. Length without spine $16.3 \mu$, Breadth without spine $17.2 \mu$, Isthmus $5.6 \mu$. Hab. 8. Second record in Japan. (P1. 2. f. 27.)

97. A. triangularis Lagerh. in West p. 97. pl. 114. f. 11-13, 17. 1911. Hab. 3. Distribution in Japan: Not general.

98. Micrasterias truncata (Corda) Bréb. in West p. 82. p1.42. f.1-8. 1905. Hab. 13. Distribution in Japan: Not general but often met with in sphagnum-moor of the alpine and subalpine regions.

99. M. denticulata Bréb. var. angulosa (Hantz.) W. \& G. S. West in p. 107. pl. 50. f. 3, 4. 1905. Hab. 8. Distribution in Japan: Frequently met with but scarce in alpine region. 
100. M. Thomasiana Arch. in West p.110. pl.51. f.3-6. 1905. Length $224 \mu$, Breadth $192 \mu$, Isthmus $31 \mu$. Hab. 21. Distribution in Japan: Not general.

101. Staurastrum alternans Bréb. in West p. 170. pl. 126. f. 8, 9. 1911. Hab. 11-13. Distribution in Japan: General. (P1. 2. f. 4.)

102. St. apiculatum Bréb. in West p.6. pl.129. f.6-8. 1923. Length without spine $21 \mu$, Breadth without spine $19.6 \mu$, Isthmus $5.6 \mu$. Hab. 1. Distribution in Japan: General. (PI. 2. f. 25.)

103. St. brachiatum Ralfs in West \& Carter p. 88. pl.141. f.14, 15, pl.142. f. 1-7. 1923. Hab. 2, 3, 8, 11, 12. Distribution in Japan: General in sphagnum-bogs.

104. St. hirsutum (Ehrenb.) Bréb. in West \& Carter p.65. pl. 138. f.4-6. 1923. Length without spine $39-47 \mu$, Breadth without spine $36-47 \mu$, Isthmus $11-15 \mu$. Hab. $1-3,8,10,14,15,20,21$. Distribution in Japan: Frequently met with in sphagnum moor of high altitude. (P1. 2. f. 6.)

105. St. margaritaceum (Ehrenb.) Menegh. in West \& Carter p. 131. pl 150. f.59. 1923. Hab. 1-3,5-8,10,12,14. Distribution in Japan: General, especially in sphagnum moors.

105a. var. robustum W. \& G.S. West in West \& Carter p.133. pl.150. f.13. 1923. Hab. 3, 4. Distribution in Japan: Rather rare.

106. St. micron West in West \& Carter p. 123, pl. 149. f. 6. 1923. Length with proc. $15.4 \mu$, Breadth with proc. $16.8 \mu$, Isthmus $7 \mu$. Hab. 4, 8. Distribution in Japan: Not general but often met with in sphagnum-bogs of the alpine and subalpine regions. (P1. 2. f. 18.)

107. St. erasum Bréb. in West \& Carter p.71. pl.137. f.9-11. 1923. Hab. 17. Distribution in Japan: General but rare in the high altitude.

108. St. forficulatum Lund. var. verrucosum Grönblad in p.64. pl.3. f. 47,50-51. 1920. Length with proc. $44.8 \mu$, Breadth with proc. $42 \mu$, Isthmus $14 \mu$. Hab. 9. New to Asia. (P1. 2. f. 1, 22.)

109. St. asterioideum West var. nanum (Wille) Grönblad in p.418. f. 29-31. 1948. Hab. 17. Distribution in Japan: General but not known at all.

110. St. dispar Bréb. forma W. \& G.S. West in p. 187. pl.127. f. 7. 1911. Length 22-26 $\mu$, Breadth 22-26 $\mu$, Isthmus 8-9 $\mu$. Hab. 1, 17,21,22. Distribution in Japan: Widely distributed but not known in general.

111. St. furcatum (Ehrenb.) Bréb. in West \& Carter p. 173. pl.155. f. 1-4. 1923. Hab. 2, 12, 13. Distribution in Japan: General but not known at all.

112. St. muticum Bréb. in West p.133. p1.118. f. 16-20. 1911. Length 21-23 $\mu$, Breadth 19.7-22 $\mu$, Isthmus 5.6-6.4 $\mu$. Hab. 8, 12. Distribution in Japan: General but. not known.

113. St. laevispinum Biss. in West \& Carter p.90. p1. 141. f. 17,18. 1923. Length $21.5 \mu$, Breadth $17 \mu$, Isthmus $8.6 \mu$. Hab. 8. New to Japan.

114. St. Simonyi Heimerl in West \& Carter p. 45. pl. 135. f. 1-4. 1923. Length without spine $21.5 \mu$, Breadth without spine $21.5 \mu$, Isthmus $6.4 \mu$. Hab. 1-3, 6-13, 15, 22 . 
114a. var. sparse-aculeatum (Schmidle) Hirano, comb. nov. Syn. St. sparseaculeatum Schmidle in Österr. Bot. Ztschr. p. 31. pl 16. f. 2 ). 1895. Length without spine 19.6-23.7 $\mu$, Breadth without spine 19.4-19.6 $\mu$, Isthmus 5.6-7.7 $\mu$. This is a form which possesses well developed spines. New to Asia. (P1. 2. f. 7.)

115. St. trihedrale Wolle in West p.260. pl.16. f. 29. 1896. Length 38.7-44.8 $\mu$, Breadth 27-30 $\mu$, Isthmus 9.5-12.6 $\mu$. Hab. 2, 17. New to Asia. (P1. 2. f. 8.)

116. St. punctulatum Bréb. in West p.179. pl.127. f. 8,11,13,14. 1911. Length $31 \mu$, Breadth $31 \mu$, Isthmus $14 \mu$. Hab. 21-23. Distribution in Japan: Not general.

116a. var. Kjellmani Wille in West p. 182. pl.127. f.13.17-19,21,22. 1911. Length $33.6 \mu$, Breadth $28 \mu$, Isthmus $15.4 \mu$. Hab. 21. Rare variety in Japan. (P1. 2. f. 30.)

117. St. scabrum Bréb. in West \& Carter p. 81. pl. 140. f. 1, 2. 1923. Length $28 \mu$, Breadth $28 \mu$, Isthmus $11 \mu$. Hab. 3,10-12. Frequent in sphagnum moor of Japan.

118. St. O'Mearii Arch. in West \& Carter p.13. pl.132. f. 5-8. 1923. Length without spine $14 \mu$, Breadth without spine $14 \mu$, Isthmus $9.8 \mu$. Hab. 3, 8, 11-14. Distribution in Japan: Rare, this is a second record. (P1. 2. f. 9.)

118a. forma parallela Ström in p.237. pl.6. f.2,3. 1926. Length without spine $22.4 \mu$, Breadth without spine $21.5 \mu$, Isthmus $13 \mu$. Hab. 3. Second record in Japan.

119. St. hexacerum (Ehrenb.) Wittr. in West \& Carter p. 138. pl.142. f. 11-14. 1923. Length $22.4 \mu$, Breadth with spine $28 \mu$, Isthmus $9.8 \mu$. Hab. 23. Rare. (P1. 2. f. 15)

120. St. echinatum Bréb. in West \& Carter p.56. pl.137. f. 12. 1923. Length $23.6 \mu$, Breadth $23.6 \mu$, Isthmus $10.8 \mu$. Hab. 17. New to Japan.

121. St. sexcostatum Bréb. var. productum West in West \& Carter p. 148. pl. 150. f. 15. 1923. Length $36 \mu$, Breadth with proc. $39 \mu$, Isthmus $13 \mu$. Hab. 17. New to Asia. (P1. 2. f. 21.)

122. St. senarium (Ehrenb.) Ralfs in West \& Carter p.175. p1.156. f.3. 1923. Hab. 11, 12, 14. Distribution in Japan: General.

123. St. spongiosum Bréb. in West \& Carter p.76. pl.140. f.14. 1923. Length without proc. $49.5 \mu$, Breadth without proc. $43 \mu$, Isthmus $21.5 \mu$. Hab. 8. New to Asia. (P1. 2. f. 31.)

124. St. inconspicuum Nordst. in West \& Carter p. 86. pl. 141. f.4-7. pl.142. f. 8. 1923. Hab. $2,3,8,11,14$. Distribution in Japan: General but not known.

125. St. Hystrix Ralfs in West \& Carter p. 60. pl.136. f. 1. 1923. Hab. 1-4,6-8, 10-14. Distribution in Japan: General in the sphagnum bogs of alpine and subalpine region.

126. St. inflexum Bréb. in West \& Carter p. 108. pl.143. f.7,8. 1923. Length $28 \mu$, Breadth with proc. $33.6 \mu$, Isthmus $9.8 \mu$. Hab. 22. Already known from Mt. Hira. Second record in Japan. (P1. 2. f. 3.)

127. St. aculeatum (Ehrenb.) Menegh. var. ornatum Nordst. in Krieger p. 64. p1.2. f. 5, 6. 1938. Length $38.7 \mu$, Breadth $30 \mu$, Isthmus $11 \mu$. Hab. 16. New to Asia 128. St. crenulatum (Näg.) Delp. in West \& Carter p.110. pl.143. f. 9-13 1923, Length $17 \mu$, Breadth without proc. ca. $23.7 \mu$, Isthmus $7.7 \mu$. Hab. 7, 8. New to Asia. 
(P1. 2. f. 17.)

128a. var. continentale Messikommer in p.207. pl.8. f.9. 1928. Length $25.8 \mu$, Breadth $25.8 \mu$, Isthmus $8.6 \mu$. Hab. 8. New to Asia. (Pl. 2. f. 19.)

129. St. cyrtocerum Bréb. in West \& Carter p. 135. pl. 149. f.9. pl.150. f.4. 1923. Length $36 \mu$, Breadth with proc. $42 \mu$, Isthmus $16.8 \mu$. Hab. 10, 23. Second record in Japan.

130. St. dejectum Bréb. in West \& Carter p. 7. pl.129. f. 9-12. 1923, Hab. 10, 23. Distribution in Japan: General. (Pl. 2. f. 23.)

131. St. Dickiei Ralfs var. circulare Turn. in West \& Carter p.5. pl.129. f. 16. 1923. Length $32-37 \mu$, Breadth without spine 30-32 $\mu$, Isthmus $10 \mu$. Hab. 5, 8. Second record in Japan. (P1. 2. f. 14.)

132. St. mutilatum Lund. in p.74. p1.5. f. 3. 1871. Length $44.8 \mu$, Breadth $33.6 \mu$, Isthmus $22.4 \mu$. Hab. 20. New to Asia. (PI. 2. f. 20.)

133. St. proboscideum (Bréb.) Arch. in West \& Carter p.129. pl.143. f. 14-16. 1923. Length $36.4 \mu$. Breadth $31 \mu$, Isthmus $16.8 \mu$. Hab. 2. New to Japan.

131. St. polymorphum Bréb. var. Grönbladii Hirano in p. 67. f. 8. 1948. Hab. 6. Distribution in Japan: Rare.

135. St. orbiculare Ralfs var. depressum Roy \& Biss. in West p.158. pl.124. f. 17-19. 1911. Hab. 1, 2, 8, 12, 14. Distribution in Japan: General. (P1. 2. f. 26.)

136. St. clepsydra Nordst. in West p. 152. pl.122. f. 6. 1911. Length $30 \mu$, Breadth $28 \mu$, Isthmus $11 \mu$. Hab. 13. New to Asia. (PI. 2. f. 10.)

136a. var. sibericum (Borge) W. \& G.S. West in p. 152. pl.122. f.9, 10. 1911. Length $15 \mu$, Breadth 15-17 $\mu$, Isthmus $9 \mu$. Hab. 7 and also in small ponds of Mt. Yakushi and Mt. Kaminotake. New to Japan. (PI. 2. f. 16.)

137. St. pileolatum Bréb. in West p. 127. pl. 118. f. 11-13. 1911. Length 34.4-38.7 $\mu$, Breadth 21-23.7 $\mu$, Isthmus $17.2 \mu$ Hab. 1,3,4,7, 8, 10,11,22. Frequently found in the sphagnum-bogs of the high altitude of northern Japan.

138. St. pilosum (Näg.) Arch. in West \& Carter p. 63. pl. 1i 8. f. 1-3. 1923. Length without spine $43 \mu$, Ereadth without spine $43 \mu$, Isthmus $15 \mu$. Hab. 6. New to Japan.

139. St. varians Racib. forma truncata Gutw. in Messikommer p.348. pl.2. f.21. 1927. Length $33.6 \mu$, Breadth $29.2 \mu$, Isthmus $15 \mu$. Hab. 8, 13,14. Second record in Japan. (P1. 2. f. 2.)

140. St. controversum Bréb. in West \& Carter p.162. pl.154. f. 1-4. 1923. Hab. 12. Distribution in Japan: Rather rare.

141. St. wandae Racib. var. brevispinum Grönblad in p.63. f. IV.1. 1938. Length without spine $22.4 \mu$, Breadth without spine 16.8-17.6 $\mu$, Isthmus 12.6-14 $\mu$. Hab. 3, 12-14. Distribution in Japan: Confined to the alpine and subalpine regions in central and northern Honshū. (P1. 2. f. 24.)

142. Hyalotheca dissiliens (Sm.) Bréb. in West \& Carter p.2:9. pl. 161. f.16-27. 1923. Length $17 \mu$, Breadth $28 \mu$. Hab. 9, 14. Distribution in Japan: General.

142a. var. tatrica Racib. in West \& Carter p. 234. pl.162. f. 19. 1923. Hab. 3,4, 
$7,8,11-13$. Distribution in Japan: General.

143. Hy. mucosa (Mert.) Ehrenb. in West \& Carter p. 23j. pl.162. f. 1-4. 1923. Hab. 8. New to Japan.

144. Spondylosium planum (Wolle) W. \& G.S. West in West \& Carter p. 222. pl. 160. f. 23-25. 1923. Length $8.4 \mu$ Breadth $9 \mu$, Isthmus $5 \mu$. Hab. 10, 12, 14, 23. New to Japan.

145. Sp. pulchellum Arch. in West \& Carter p. 227. pl.161. f. 1-3. 1923. Length $12.6 \mu$, Breadth $12.6 \mu$, Isthmus $4.2 \mu$. Hab. 2. Distribution in Japan: Not general.

146. Desmidium coarctatum Nordst. in West \& Carter p. 252. p1.165. f.1, 2. 1923. Hab. 9. Distribution in Japan: General.

147. D. Swartzii Ag. in West \& Carter p. 246. pl. 163. f. 5-8. 1923. Hab. 14. Distribution in Japan : General.

148. Sphaerozosma granulatus Roy \& Biss. in West \& Carter p. 213. pl.160. f.6, 7. 1923. Length $9.8 \mu$, Breadth $7.6 \mu$, Isthmus $5.6 \mu$. Hab. 1,2,3,7,8. Distribution in Japan : General.

149. Gymnozyga moniliformis Ehrenb. in West \& Carter p. 255. pl.165. f. 8; 9. 1923. Hab. 2, 3, 6-8, 11-14. Distribution in Japan: General.

\section{References}

Cedercreutz, C. 1932. Süsswasseralgen aus Petsamo. II. Mem. Soc. pro Fauna Flor. Fenn. 7.

Dick, J. 1930. Pfälzische Desmidiaceen. Mitt. Pfälz Ver. Natk. Pollichia N. F. III.

Grönblad, R. 1920. Finnländische Desmidiaceen aus Keuru. Act. Soc. Faun. Flor. Fenn. 47.

1938. Neue und seltene Desmidiaceen. Bot. Notis.

1948. Freshwater Algae from Täcktom träsk. Bot. Notiser.

Hirano, M. 1948. Desmidiaceae novae Japonicae I. Mem. Coll. Sci. Univ. Kyoto B. 19.

1952. On the Distribution of Desmids in the Oze District. Jap. Journ. Limnol. 16.

Kossinskaja, E. K. 1933. Liste critique des Algues d'eau douce récoltées par P.Savicz au cours de l'expedition officielle 1930. Act. Inst. Bot. Ac. Sci. U.R.S.S. ser. II. 1.

1936. Desmidien der Arktis. Ibid. Plant Crypt. III.

Krieger, W. 1933-37. Desmidiaceen in R benhorst' Krypt. Fl. 13. Abt. 1.

1938. Süsswasseralgen aus Spitzbergen. Ber. Dtsch. Bot. Ges. 56.

Lundell, P. M. 1871. De Desmidiaceis, quae in Suecia inventae sunt, observationes criticae. Nov. act. Regn. Soc. Ups. ser. 3. VIII.

Messikommer, E. 1927. Beiträge zur Kenntnis Algenflora des Kantons Zürich, II. Viertelj. Naturf. Ges Zürich 72 .

1928. Die Algenflora des Hinwiler- und Oberhöfleriedes. Viertelj. Naturf. Ges. Zürich 73. 1935. Die Algenwelt der Inneren Plessuralpen. Ibid. 80.

Nordstedt, O. 1873. Bidrag till kännedomen om sydligare Norges Desmidiéer. Lund Univ. Årsskr. 9.

Okada, Y. 1936. Notes on Japanese Desmids, with special reference to the newly found species. I-IV. Bot. Mag. 50.

Ström, K. M. 1926. Norwegian Mountain Algae. Skrift Norsk. Vidensk. Akad. Oslo math.-nat. Kl. 6. West, W. \& G.S. 1896. On some North American Desmidieae. Trans. Linn. Soc. Bot. V. and Carter, N. 1904-23. A monograph of the British Desmidiaceae. vol. I-V. 

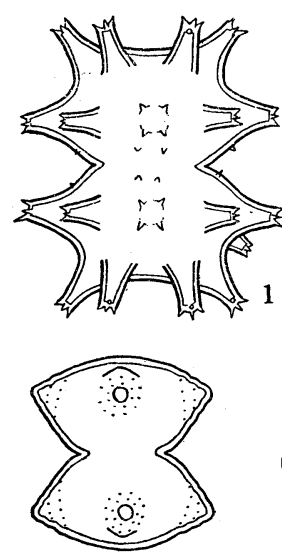

2
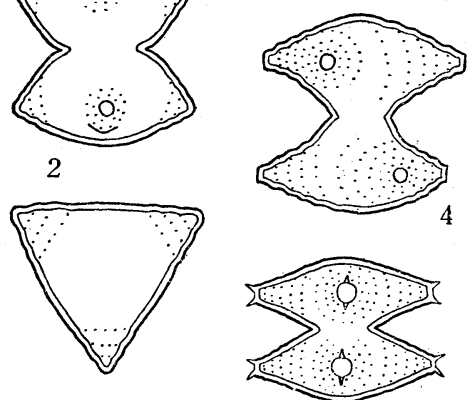

15
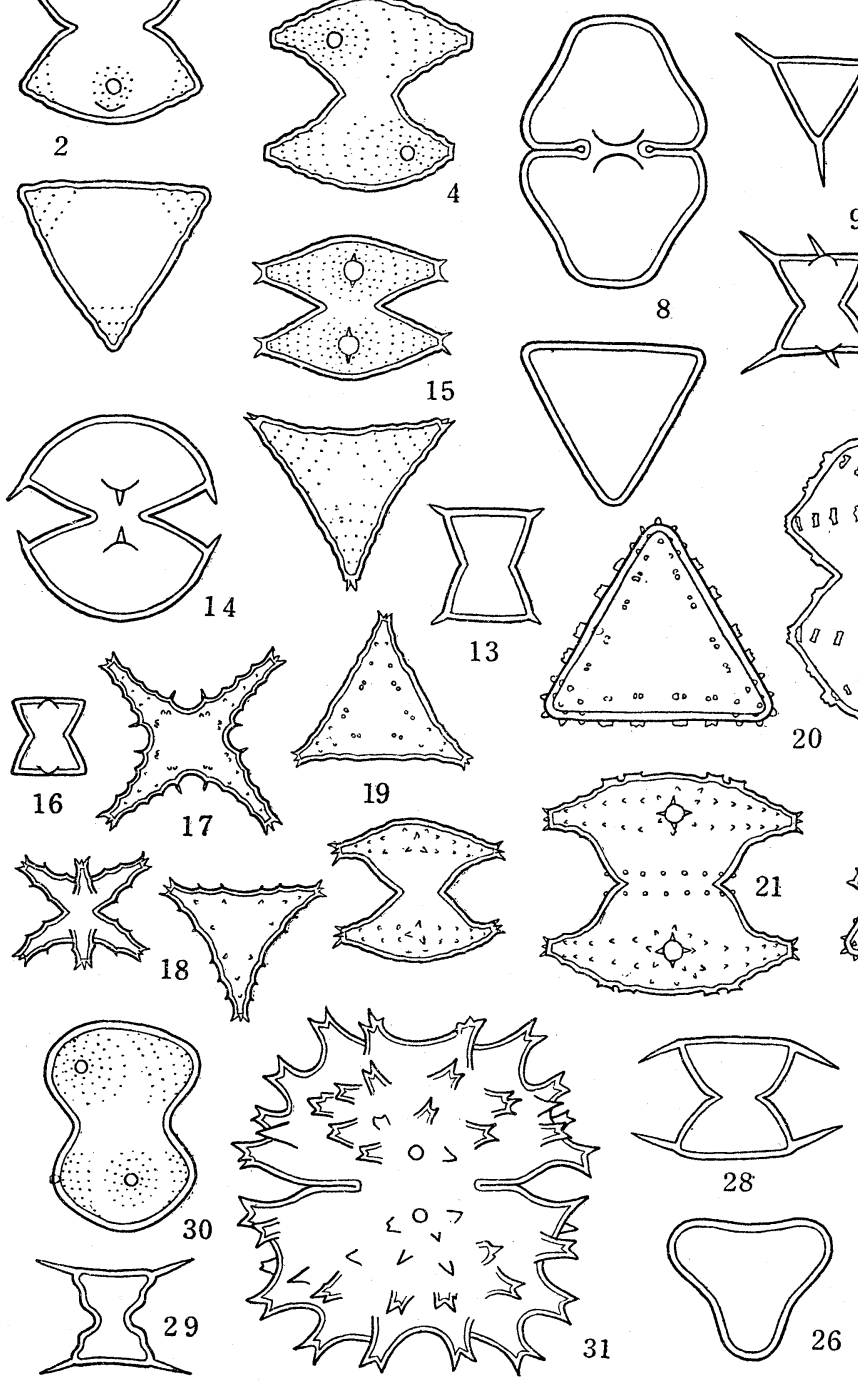

8
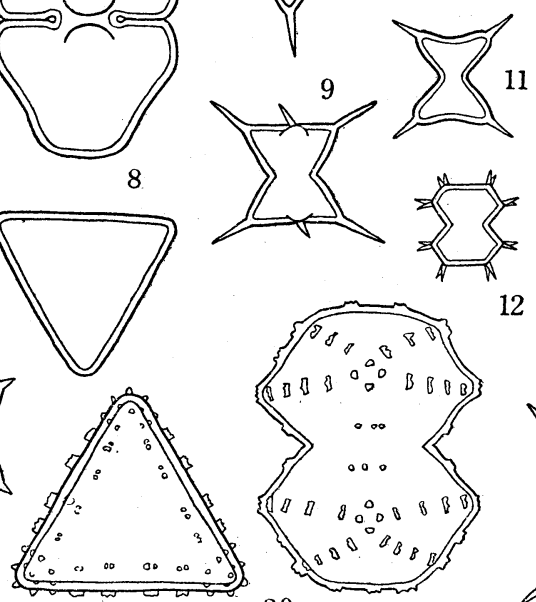

12
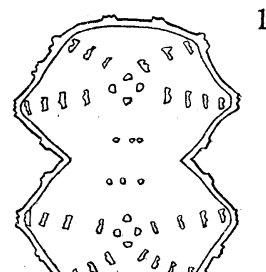

20
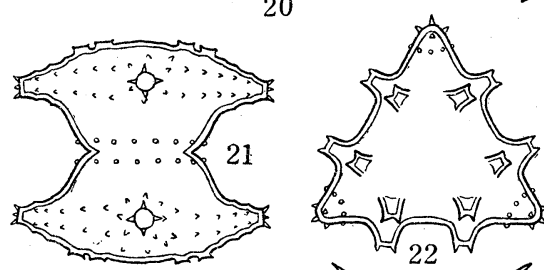

23
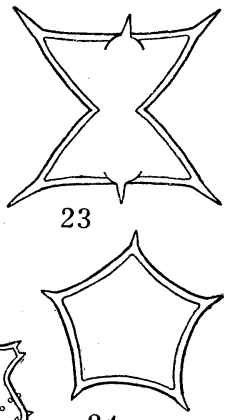

24
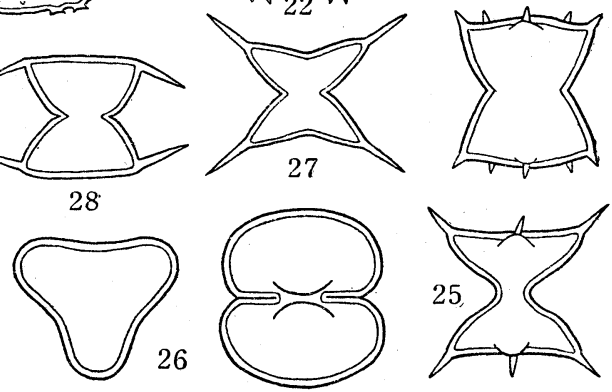

\section{Explanation of plate 2}

1. Staurastrum forficulatum var. verrucosum 2 2. St. varians f. truncata 3. St. inflexum 4. St. alternans 5. Xanthidium cristatum var. uncinatum 6. St. hirsutum 7. St. Simonyi var. sparse-aculeatum 8. St. trihedrale 9. St. O'Mearii 10. St. Clepsydra 11. Arthrodesmus Incus f. minor 12. Xanthidium concinnum 13. A. crassus 14. St. Dickiei var. circulare 15. St. hexacerum 16. St. Clepsydra var. sibericum 17. St. crenulatum 18. St. micron 19. St. crenulatum var. continentale $20 . \quad$ St. mutilatum 21. St. sexcostatum var. productum 22. St. forficulatum var. verrucosum 23. St. dejectum 24. St. wandae var. brevispinum 25. St. apiculatum 26. St. orbiculare var. depressum 27. Arthrodesmus phimus var. occidentalis 28. A. Incus var. Ralfsii f. latiuscula 29. A. Incus var. indentatus 30. Staurastrum punctulatum var. Kjellmani 31 . St. spongiosum $\times 640$ 